\title{
A/M Area Metallurgical Laboratory: Summary of Phase I CharacterizationWell Installation, Cone Penetrometer Testing and Soil Coring for Soil Headspace Analysis
}

by

R. S. Van Pelt

Westinghouse Savannah River Company

Savannah River Site

Aiken, South Carolina 29808

T. Dunbar

This paper was prepared in connection with work done under the above contract number with the U.S.

Department of Energy. By acceptance of this paper, the publisher and/or recipient acknowledges the U.S. Government's right to retain a nonexclusive, royalty-free license in and to any copyright covering this paper, along with the right to reproduce and to authorize others to reproduce all or part of the copyrighted paper. 


\section{DISCLAIMER}

This report was prepared as an account of work sponsored by an agency of the United States Government. Neither the United. States Government nor any agency thereof, nor any of their employees, makes any warranty; express or implied; or assumes any legal liability or responsibility for the accuracy, completeness, or usefulness of any information, apparatus, product, or process disclosed, or represents that its use would not infringe privately owned rights. Reference herein to any specific commercial product, process, or service by trade name, trademark, manufacturer, or otherwise does not necessarily constitute or imply its endorsement, recommendation, or favoring by the United States Government or any agency thereof. The views and opinions of authors expressed herein do not necessarily state or reflect those of the United States Government or any agency thereof.

This report has been reproduced directly from the best available copy.

Available to DOE and DOE contractors from the Office of Scientific and Technical Information, P.O. Box 62, Oak Ridge, TN 37831; prices available from (615) 576-8401.

Available to the public from the National Technical Information Service, U.S. Department of Commerce, 5285 Port Royal Road, Springfield, VA 22161. 


\section{DISCLAIMER}

\section{Portions of this document may be illegible in electronic image products. Images are produced from the best available original document.}


A/M AREA METALLURGICAL LABORATORY: SUMMARY OF PHASE I CHARACTERIZATION WELL INSTALLATION, CONE PENETROMETER TESTING AND SOIL CORING FOR SOIL HEADSPACE ANALYSIS (U)

Robert S. Van Pelt

Toney Dunbar

PUBLICATION DATE:

October 1995 
WSRC-RP-95-1553

\section{A/M AREA METALLURGICAL LABORATORY:} SUMMARY OF PHASE I CHARACTERIZATION WELL INSTALLATION, CONE PENETROMETER, TESTING AND SOM CORING FOR

SOM HEADSPACE ANALYSIS (U)

Robert S. Van Pelt

Toney Dunbar .

PUBLICATION DATE:

October 1995

Authorized Derivative Classifier

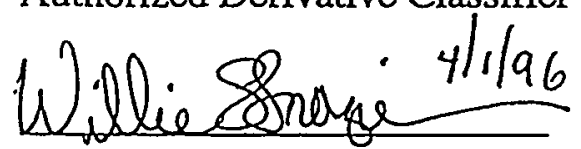

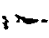

. 


\section{TABLE OF CONTENTS}

EXECUTIVE SUMMARY.

1.0 OBJECTIVES

2.0 GEOLOGY AND HYDROGEOLOGY OF THE M AREA................................................ (WATER TABLE), LOST LAKE, AND MIDDLE SAND AQUIFER ZONES

2.1 A/M Area: Met Lab HWMF Geology ..................................................................3

2.1.1 Tertiary Geology of the A/M Area: Met Lab HWMF......................................

2.2 A/M Area: Met Lab HWMF Hydrogeology ........................................................

3.0 STEED POND AQUIFER (M AREA, LOST LAKE, AND MIDDLE .............................11 SAND AQUIFER ZONES) CONTAMINATION HISTORY

4.0 PHASE I CHARACTERIZATION: MONITOR WELL INSTALLATION, SOIL CORING CONE PENETROMETER TESTING

4.1 Monitor Well Installation.................................................................................13

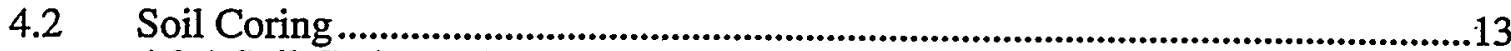

4.2.1 Soil Coring Laboratory Analysis for Yolatile Organic Compounds..............16

4.3 Cone Penetrometer Testing..................................................................................19

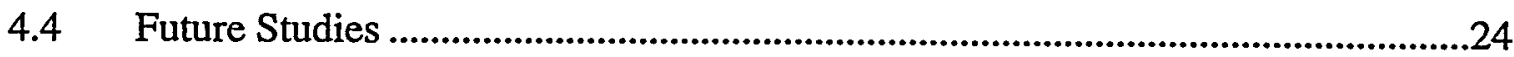

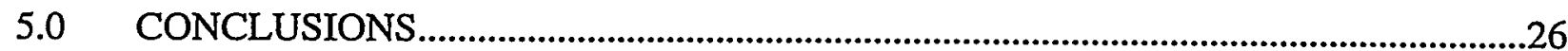

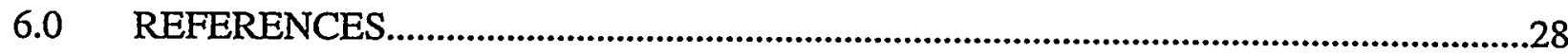




\section{LIST OF FIGURES}

Number

Title

Page

Figure 1. $\quad$ A/M Area Metallurgical Laboratory: Phase I Location Map.....................................2

Figure 2. Comparison of Chrono-, Litho-, and Hydrostratigraphic Units at SRS....................4

Figure 3. Hydrostratigraphic Chart for the A/M Area...................................................................

Figure 4. Cross-sectional View of TCE Contamination: North-South Transect.....................29

Figure 5. Cross-sectional View of PCE Contamination: North-South Transect.....................30

Figure 6. Cross-sectional View of TCE Contamination: East-West Transect .......................31

Figure 7. - Cross-sectional View of PCE Contamination: East-West Transect..........................32

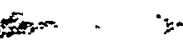




\section{LIST OF TABLES}

Number

Title

Page

Table 1. Well Construction and Soil Boring Details...........................................................14

Table 2. Bulk Sediment Headspace Results and Estimated ................................................15 Groundwater Concentrations

Table 3. Groundwater Sample Location, Depth, and Analysis. .23 


\section{LIST OF ACRONYMS}

$\begin{array}{ll}\text { cm/s } & \text { centimeters per second } \\ \text { DOE } & \text { Department of Energy } \\ \text { GC-MS } & \text { Gas Chromatography-Mass Spectrometry } \\ \text { HWMF } & \text { Hazardous Waste Management Facility } \\ \text { Met Lab } & \text { Metallurgical Laboratory } \\ \text { MSL } & \text { Mean Sea Level } \\ \text { NODs } & \text { Notice of Deficiencies } \\ \text { PCE } & \text { Perchloroethylene } \\ \text { PDWS } & \text { Primary Drinking Water Standards } \\ \text { ppb } & \text { parts per billion } \\ \text { ppm } & \text { parts per million } \\ \text { RCRA } & \text { Resource Conservation and Recovery Act } \\ \text { SCDHEC } & \text { South Carolina Department of Health and Environmental Control } \\ \text { SRTC-ESS } & \text { Savannah River Technology Center - Environmental Sciences Section } \\ \text { SRS } & \text { Savannah River Site } \\ \text { TCE } & \text { Trichloroethylene } \\ \mu \text { /g } & \text { micrograms per gram } \\ \mu \text { g/L } & \text { micrograms per liter } \\ \text { VOCs } & \text { Volatile Organic Compounds } \\ \text { WSRC } & \text { Westinghouse Savannah River Company } \\ & \end{array}$




\section{EXECUTIVE SUMMARY}

This report documents the Phase I characterization of chlorinated solvent contamination in the regulatory-defined uppermost aquifer (includes the $\mathrm{M}$ Area, Lost Lake and middle sand aquifer zones) within the Metallurgical Laboratory (Met Lab) of the A/M Area. Included is a brief description of the geology, hydrogeology, Phase I characterization activities and results, and path forward. The characterization of the uppermost aquifer is part of the overall A/M Area Groundwater Program, and, in part, fulfills the South Carolina Department of Health and Environmental Control (SCDHEC) request for data that delineates that lateral and vertical extent of contamination in the water table (M-Area aquifer zone) and underlying confined aquifers (Lost Lake and middle sand aquifer zones) within the vicinity of, and downgradient to, the Metallurgical Laboratory HWMF. Well installations also provide the necessary point of compliance monitoring wells for this HWMF as required by regulation.

The 1994 Phase I characterization consisted of installing seven monitor wells and drilling one soil boring at the Metallurgical Laboratory HWMF. Cone penetrometer testings (six locations) were deployed to optimize placement of the water table wells and to collect information on the subsurface hydrogeology. Soil gas samples were collected at three locations using the Bruel and Kjaer; groundwater samples were collected (two locations) using the hydrocone method and analyzed for volatile organic compounds (VOCs), primarily trichloroethylene (TCE) and perchloroethylene (PCE). Soil samples were collected from the one soil boring at 10-foot intervals beginning at the surface to the target depth of 290 feet below surface; the soil headspace was analyzed for VOC contamination. Bulk samples $\left(3-5 \mathrm{~cm}^{3}\right)$ were collected and analyzed for TCE and PCE. Analyses were conducted by the Savannah River Technology Center (SRTC) Environmental Sciences Section (ESS). A total of 37 samples were selected for analysis, with VOC concentrations ranging from $<0.001 \mu \mathrm{g} / \mathrm{g}$ to $0.543 \mu \mathrm{g} / \mathrm{g}$. Approximately $68 \%$ of the samples were below detection for both compounds. Maximum TCE and PCE sediment concentrations ( 0.5443 and $0.074 \mu \mathrm{g} / \mathrm{g}$, respectively) were detected in AMB-SB1. These sediment concentrations are equivalent to estimated water concentrations of 2940 and $390 \mathrm{ppb}$, respectively.

Core AMB-SB1 generally showed detectable VOCs over a 20 to 60 foot interval (e.g., 22-152 foot; 212-232 foot; and 262-272 foot intervals). Based on examination of the field geologic descriptions, depths greater than 150 feet represent water bearing zones between or just 
above/below fine grain sediments (aquitards); the higher sediment concentrations appear to be retarded or "trapped" to some degree by the underlying finer-grained clayey or silty layers. Depths shallower than 150 feet represent the unsaturated (vadose) zone. Fine grain sediments (i.e., clays and silts) occur as discrete intervals and as minor components of sandier beds. These fine grain sediments act to retard the vertical and lateral migration of chlorinated solvents.

Estimated water concentration results were combined with monitor well data (2nd quarter 1994) to generate cross-sectional plume maps for the Metallurgical Laboratory HWMF. A comparison between the various data groups indicate a general agreement with regard to level of TCE and PCE contamination.

As the result of past surface disposal practices, a plume consisting primarily of TCE and PCE exists in the.uppermost aquifer within the Metallurgical Laboratory HWMF. The contaminants TCE and PCE have moved within and through the vadose zone into the aquifer zones which comprise the uppermost aquifer. These include, in descending order, the M Area, Lost Lake, and middle sand aquifer zones. Historically, groundwater from the uppermost aquifer has not been used onsite for process or domestic use. The groundwater contamination is onsite and flows southerly (excluding the $\mathrm{M}$ Area aquifer zone which is recognized as bi-directional to radial flow) direction, away from the nearest Savannah River Site (SRS) boundary. As a result, the potential for human health impact and exposure is minimal because the contamination is confined to the subsurface and is within the SRS boundatiry.

Overall, the results of this investigation corroborate earlier studies which suggest that the primary source of TCE and PCE contamination in the aquifers underlying the Metallurgical Laboratory HWMF is from the SRTC complex. Distribution of the VOC concentrations suggest that the contaminants are primarily moving above the surface of lower permeability zones within the M Area (water table), Lost Lake, and middle sand aquifer zones.

A characterization program has been developed which includes a phased approach toward data collection. Currently, the first phase (conducted in 1994 as part of the A/M Area Phase X Drilling Project: Met Lab Characterization Phase I) has been completed; additional characterization has been identified and will be conducted as a Phase II during 1995. Phase II will include the use of proven investigative methods, such as soil headspace analyses and cone penetrometer testing. 


\subsection{OBJECTIVES}

The 1994 Met Lab Phase I Characterization: Monitor Well Installation and Soil Coring for Soil Headspace (Figure 1) represents an integral part of the A/M Area Metallurgical Laboratory Characterization Program. The study objective was to install seven monitor wells and one soil boring in order to obtain additional hydrogeologic and groundwater quality information necessary to define the vertical and lateral extent of VOC contamination within the vicinity of the Met Lab HWMF.

The characterization efforts of the 1994 Met Lab Phase I Characterization Project satisfy regulatory commitments of SRS to comply with the Notice of Deficiencies (NODs) to the Met Lab Part B Permit Renewal Application issued (1/20/94) by SCDHEC. In response to the NODs, SRS planned to obtain additional hydrogeologic and groundwater quality data to further define the groundwater plumes near the Met Lab HWMF, and improve the monitoring of the point of compliance. 


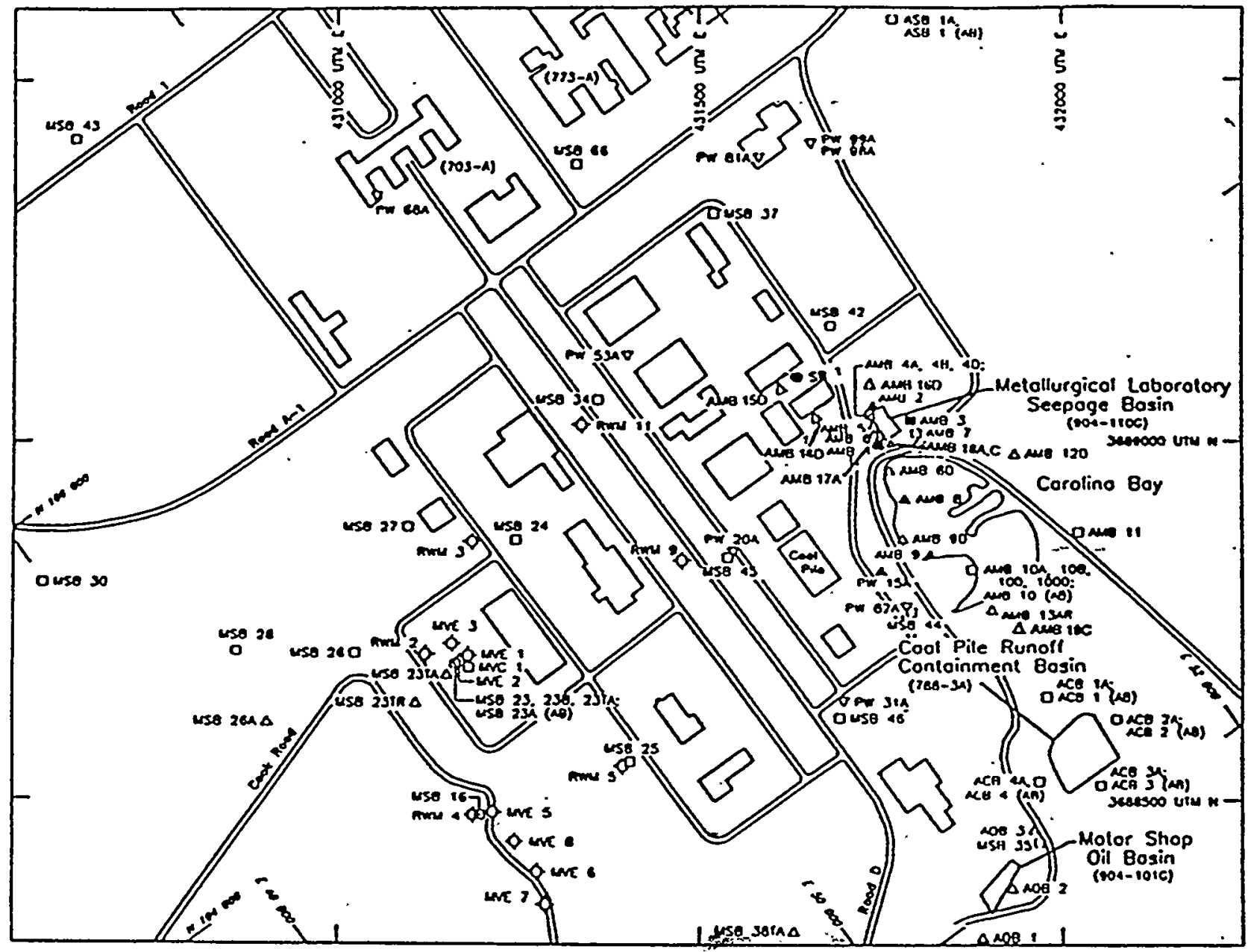

Well Types

\section{LEGEND}
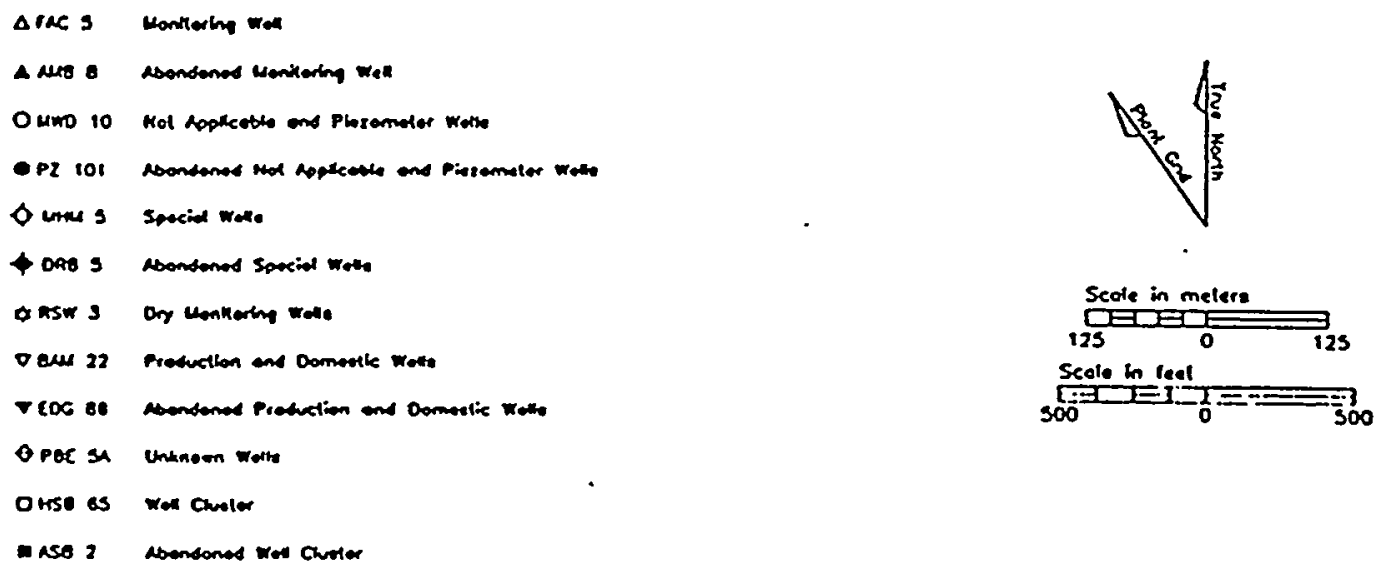

Figure 1. A/M Area Metallurgical Laboratory: Phase I Location Map 


\subsection{GEOLOGY AND HYDROGEOLOGY OF THE M AREA (WATER TABLE), LOST LAKE, AND MIDDLE SAND AQUIFER ŻONES}

This section includes a brief discussion of:

- the geology of Tertiary age sediments that form the M Area, Lost Lake, and middle sand aquifer zones

- the hydrogeology of the M Area, Lost Lake, and middle sand aquifer zones

A complete description of the geology and hydrogeology is presented in Aadland etal., 1995.

\subsection{A/M Area: Met Lab HWMF Geology}

The SRS is located on the Upper Atlantic Coastal Plain. The province dips gently seaward and ranges from Late Cretaceous age to Recent age. The thickness of the Atlantic Coastal Plain increases from 0 feet at the Fall Line to more than 4000 feet at the coast. Regional dip is to the southeast, at $35 \mathrm{feet} / \mathrm{mile}$ (Klitgord and Behrendt, 1979) although beds dip and thicken locally in other directions because of locally variable depositional regimes and differential relief on basement features.

The stratigraphic section thins and undergoes facies changes from the south and east toward the northwest and north across the SRS region. In the A/M Area, the section contains a higher percentage of clastic sediment and very little carbonate; elsewhere at the SRS, carbonate-rich units play a significant role in controlling hydraulic characteristics. Because of facies changes and the thinning of important units, local controls are especially important in the $\mathrm{A} / \mathrm{M}$ Area. The Upper Atlantic Coastal Plain province is divided into several formations and groups principally on age and lithology. The discussions in this report are limited to the Tertiary age sediments of the $\mathrm{A} / \mathrm{M}$ Area because these sediments comprise the $\mathrm{M}$ Area (water table) and Lost Lake aquifer zones, and the underlying Crouch Branch Confining Unit [(containing the middle sand aquifer zone) (Figure 2)]; for additional information on the geologic setting of the area, refer to Aadland et al., 1995. 


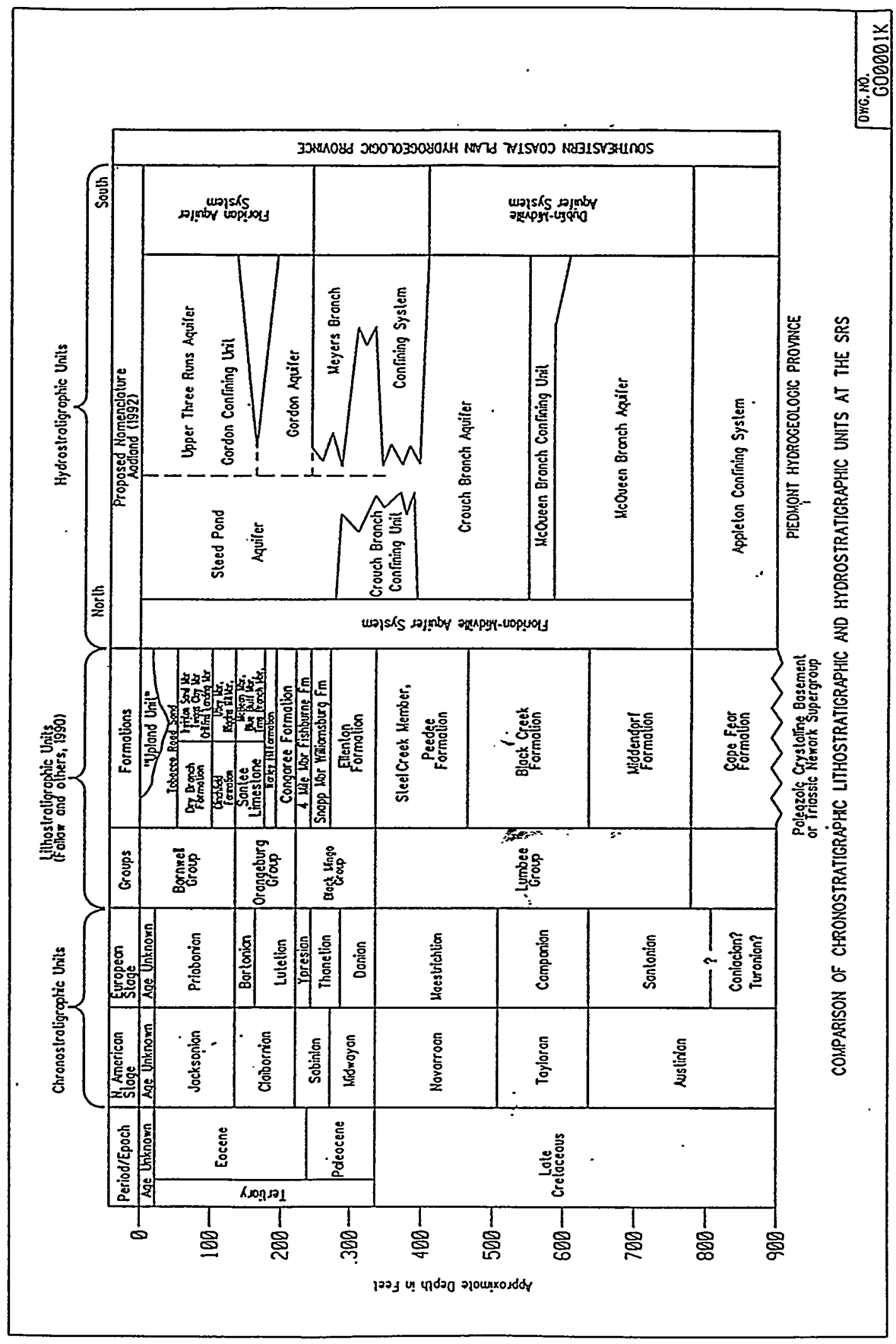

Figure 2. Comparison of Chrono-, Litho-, and Hydrostratigraphic Units at SRS 


\subsubsection{Tertiary Geology of the A/M Area: Met Lab HWMF}

The Tertiary age sedimentary sequence in the A/M Area has been delineated using lithologic data from extensive core data at SRS, as well as geophysical data from A/M-Area wells. The Tertiary age Coastal Plain stratigraphic units, in ascending order, are the Black Mingo Group, the Orangeburg Group, the Barnwell Group, and the Upland Unit (Figure 2).

The Black Mingo Group consists of the Sawdust Landing and Lang Syne (Lower Paleocene) formations, and the Snapp and Fourmile formations (Upper Paleocene to Lower Eocene) (Fallaw, 1991). The contact between clay and clayey sand of the Lang Syne Formation and the underlying clay bed that caps the Cretaceous Steel Creek Formation is gradational and indistinct. The top of the Lang Syne Formation ranges from 120 to 150 feet above msl,_and varies in thickness from 20 to 100 feet across the A/M Area due to erosional truncation of the sediments at the "Lang Syne-Fishburne/Congaree" contact.

In the A/M Area, the Lang Syne Formation is represented by two facies. The one facies consists of dark gray to black, poorly sorted, fine to coarse grained, clayey, silty quartz sand and dark, kaolinitic clay and clayey silt. Muscovite, feldspar, iron sulfide, and lignite are common, and induration is slight to moderate. This facies is similar to the type Lang Syne (formerly Ellenton Formation) near the center of the SRS (Siple, 1967). The sand and clay of the other facies are light colored (tan), and generally lack the sulfide antignite observed in the dark sediments. However, mica is common in places. Both facies contain pebbly zones. The light colored facies may represent upper delta plain, channel dominant environments, whereas the dark colored facies may represent lower delta plain, bay-dominant environments.

The Orangeburg Group (Middle Eocene) is subdivided into the lower Middle Eocene Congaree Formation and the upper Middle Eocene Warley Hill Formation and Santee Limestone Formation. At the SRS, these formations consist of alternating layers of sand, limestone, marl, and clay that are indicative of deposition in shoreline to shallow shelf environments.

The Congaree Formation is composed of tan, moderately to well sorted, fine to coarse quartz sands with thin clay laminae throughout. The Congaree interval attains a maximum thickness of about 30-feet near the center of the SRS. 
Unconformably overlying the Congaree Formation are 10 to 20 feet of fine-grained, often glauconitic sand and green clay beds that have been referred to respectively as the Warley Hill and Caw Caw Members of the Santee Limestone. Both the glauconitic sand and clay at the top of the Congaree Formation are assigned to the Warley Hill Formation (Fallaw, 1991).

The Warley Hill Formation in A/M Area is mostly orange and yellow, fine to coarse, poorly to well sorted quartz sand interbedded with discontinuous clay beds. Pebbles and clay clasts are common in places, and muscovite is a common detrital mineral. In the Southern Sector of $A / M$ Area, a section of micritic, shelly limestone was encountered within the Warley Hill interval. This is the only carbonate lithology encountered in A/M Area. Thickness ranges from as little as 1 foot to the northeast to more than 30 feet in the south.

The late Middle Eocene Santee Limestone Formation overlies the Warley Hill Formation. The Santee Limestone Formation consists of moderately sorted yellow and tan sand, calcareous sand and clay, limestone, and clay. The Santee Formation varies from 30 to 45 feet in thickness within the A/M Area.

The Barnwell Group (Late Eocene) is subdivided into the Clinchfield, Dry Branch, and Tobacco Road Formations. The Clinchfield Formation is present at some locations, but is not continuous enough to be correlated across the SRS. The Dry Branch Formation is similar in lithology to the Santee Formation (McBean Member) with tan, greent, yellow, änd brown clays which occur in places at various stratigraphic levels within the formation. The Dry Branch Formation is cleaner (less clay content) than the underlying McBean Member sands, or the overlying Tobacco.Road Formation sediments. The Dry Branch Formation varies in thickness from 0 to 110 feet in A/M-Area borings. The sand of the Dry Branch Formation probably accumulated in a shallow marine environment.

The Tobacco Road Formation consists of orange, red, brown, yellow, tan, and purple fine to coarse, poorly to well sorted sands. Pebbly layers are common, especially near the base. Clay clasts are fairly common, and clay layers up to 4 feet thick have been encountered in some borings. The formation outcrops at the surface at many locations throughout the SRS. The Tobacco Road Formation was probably deposited in a shallow marine environment.

The "Upland Unit" (previously mapped at SRS as the Hawthorn Formation) in A/M Area is composed of yellow, orange, purple, red, brown, and tan, fine to very coarse, poorly sorted, 
clayey, silty quartz sands. Weathered feldspar grains are abundant in some locations. Clay lenses interbedded with these sands are up to 50 feet thick. Thickness varies from not present to approximately 60 feet. The "Upland Unit" sediments were probably deposited in high energy fluvial channels, point bars, floodplains, and abandoned channels.

\subsection{A/M Area: Met Lab HWMF Hydrogeology}

A multilayer hydrologic system exists in the Coastal Plain sediments at the SRS. Confining units within the system are interspersed with more transmissive units. Aadland and Bledsoe (1990) have developed a hydrostratigraphic nomenclature system (see Figure 3) for SRS. Within this nomenclature, the basement complex underlying the Coastal Plain deposits is referred to as the Piedmont Hydrogeologic System.

This system is overlain by three aquifer systems of Coastal Plain deposits, the Midville, the Dublin, and the Floridan Aquifer Systems, separated by the Allendale and Meyers Branch Confining Systems. These Aquifer systems are separated from the lower Piedmont Hydrogeologic System by the Appleton Confining System. The Appleton Confining System is composed of poorly sorted, clayey sediments of the Cape Fear Formation.

Confining clay sediments of the middle Black Creek Formation make up the Allendale Confining Unit which separates the Midville and Dứtilin Aquifiers. The Midville Aquifer is composed of sands of the Middendorf Formation and the lower sands of the Black Creek Formation. The Dublin Aquifer includes sands of the upper Black Creek and lower Peedee Formations. As the confining systems and units thin and become discontinuous in a northerly direction at the SRS, the Midville and the Dublin Aquifer Systems are combined to form a single Dublin-Midville Aquifer System. The reader is referred to Aadland et al. (1995) for the most recent description of SRS hydrogeology and formal nomenclature.

The Floridan Aquifer System is divided into the Gordon Aquifer and the Upper Three Runs Aquifer by the Gordon Confining Unit. Congaree/Fourmile sands comprise the Gordon Aquifer, and sands of the Santee Limestone and Tobacco Road Formation comprise the Upper Three Runs Aquifer. Warley Hill and Caw Caw clays (including the "green clay") comprise the Gordon Confining Unit. 


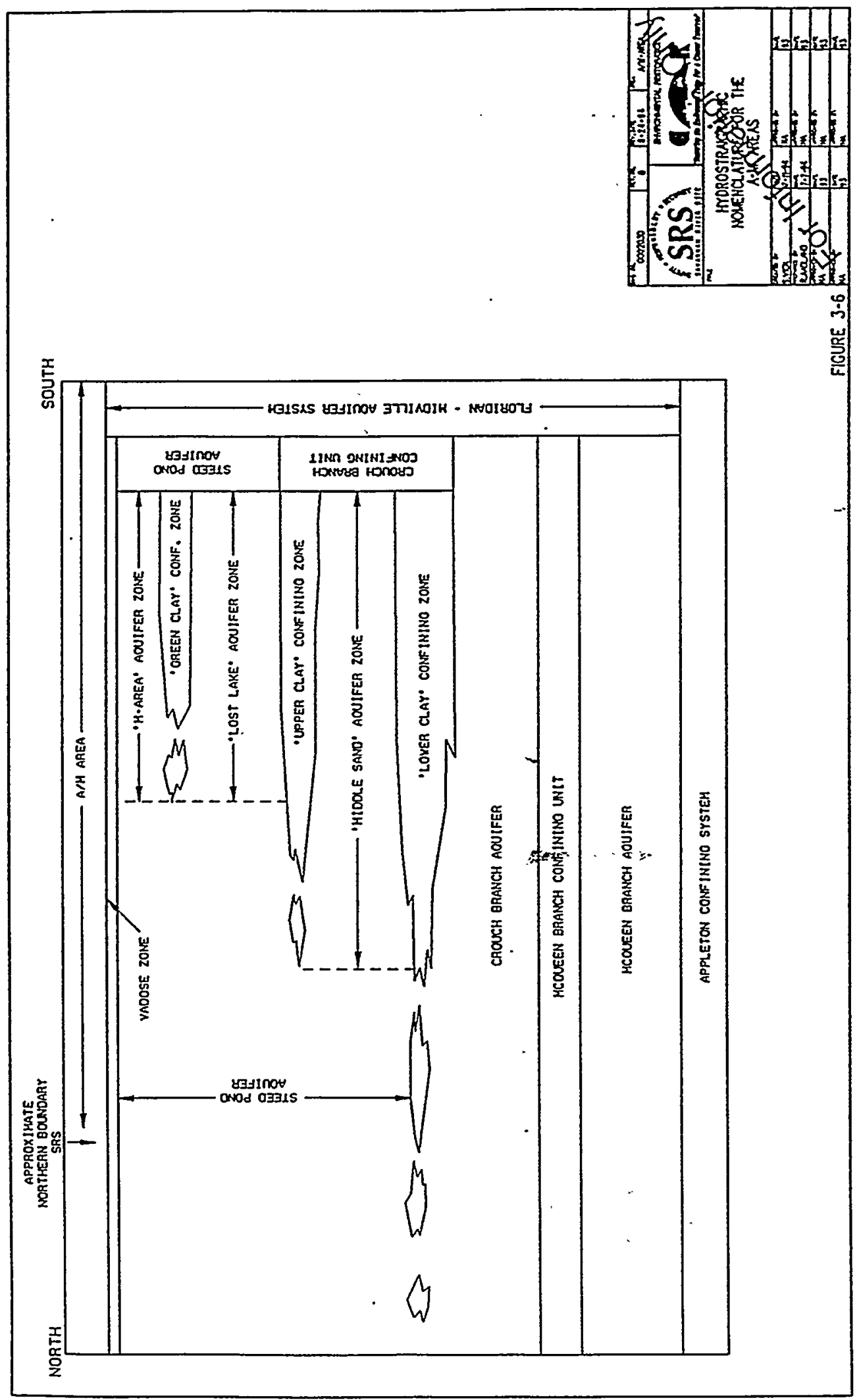

Figure 3. Hydrostratigraphic Chart for the A/M Area 
Northwest of Upper Three Runs Creek, as in the A/M-Area, the individual confining beds separating the Dublin-Midville Aquifer System and the Floridan Aquifer Systems become thin and discontinuous (Figure 3 ). In this area of SRS, the two aquifer systems combine to form the single, larger Floridan-Midville Aquifer System. This is due to the thin and sporadic character of the clay and silty clay beds correlative with the Meyers Branch Confining System and the Allendale Confining Unit. The reader is referred to Aadland et al. (1992) and Lewis and Aadland (1994) for the most recent description in A/M-Area hydrogeology.

In A/M Area, the Florida-Midville Aquifer System is divided into three aquifer units from base upwards: McQueen Branch Aquifer, the Crouch Branch Aquifer, and the Steed Pond Aquifer, separated by the McQueen Branch and the Crouch Branch Confining Units. In A/M Area, the Gordon Aquifer and the Upper Three Runs Aquifer are in hydraulic communication due to the thin, and intermittent character of the intervening clay beds.

The aquifers coalesce in the A/M Area to form the single aquifer unit, Steed Pond Aquifer. The Steed Pond Aquifer is divided into the "middle sand" and "Lost Lake" aquifer zone, and the "M-Area" aquifer zone by the upper clay confining zone and the "green clay" confining zone, respectively. These are equivalent to the Gordon Aquifer, the Upper Three Runs Aquifer, and the Gordon Confining Unit, respectively. The water table is typically located in the "M-Area" aquifer zone (Aadland et al., 1992).

For the purpose of this study, a discussion of the hydrogeology is restricted to sediments comprising the Crouch Branch Confining Unit and overlying aquifers/confining units.

The Crouch Branch Confining Unit which overlies the Crouch Branch Aquifer, is locally variable and discontinuous. The confining unit ranges in thickness from 18 to 102 feet across A/M Area. The Crouch Branch Confining Unit, from the base to the top of the unit, includes the following hydrostratigraphic sequence:

"lower clay" confining zone; "upper clay" confining zone; and "middle sand" aquifer zone

The "lower clay" confining zone is, for the most part, the most competent and continuous of the three zones. The "lower clay" confining zone thins to the north and the southwest to a point where the Steed Pond Aquifer and Crouch Branch Aquifer coalesce to form a single aquifer 
system. Across the $\mathrm{A} / \mathrm{M}$ Area the "lower clay" confining zone ranges in thickness from 2 to 50 feet. The "middle sand" aquifer zone, coalesces with permeable sediments to the north to form the Steed Pond Aquifer. The discontinuous nature of the "middle sand" aquifer zone is due to the absence of the overlying "upper clay" confining zone. The "middle sand" aquifer zone ranges from 15 to 70 feet. Groundwater flow in the "middle sand" aquifer is to the southwest. The "upper clay" confining zone of the Crouch Branch Confining Unit is discontinuous in the northern portion of the $A / M$ Area, with a variable thickness from 0 to 15 feet.

The "Lost Lake" aquifer zone of the Steed Pond Aquifer is discontinuous to the north of the A/M Area and also within a zone located in the south-central portion of the A/M Area. Where present, the thickness of the "Lost Lake" aquifer zone varies from 46 to 83 feet. A middle confining clay layer is located midway in the "Lost Lake" aquifer zone separating the aquifer zone into upper and lower aquifer zones. Groundwater flow direction in the upper "Lost Lake" aquifer is generally in the southwesterly direction for the south and west portions of $\mathrm{A} / \mathrm{M}$ Area. Groundwater flow in the lower "Lost Lake" aquifer zone is to the south-southwest

Within the Steed Pond Aquifer and overlying the "Lost Lake" aquifer zone is the "green clay" confining zone. The confining zone separates the "Lost Lake" aquifer zone from the overlying "M-Area" aquifer zone. North of the $\mathrm{A} / \mathrm{M}$ Area, where the confining zone thins and becomes absent, the "Lost Lake" aquifer zone and the "M-Area" aquifer zone coalesce into the Steed Pond Aquifer. The thickness of the "green clay" confinifrg zone ranges from 2 to 28 feet. The thickness of the confining zone may include sand layers.

The "M-Area" aquifer zone is the uppermost aquifer zone within the Steed Pond Aquifer. This aquifer zone is a water table aquifer unit that is laterally discontinuous to the north due to the pinching out of the "green clay" confining zone. Where the confining zone is absent, the "M-Area" aquifer zone coalesces with permeable sediments in the northern portion of the A/M Area, forming the water table portion of the Steed Pond Aquifer. Where present, the "M-Area" aquifer zone ranges in thickness from 37 to 180 feet.

Met Lab Phase I monitor wells and soil borings were installed in the M Area, Lost Lake, and middle sand aquifer zones of the Steed Pond Aquifer. 


\subsection{Steed Pond Aquifer (M Area, Lost Lake, and Middle Sand aquifer zones) Contamination History}

Groundwater contamination within the Metallurgical Laboratory HWMF is the result of previous waste disposal practices, once considered state of the art. The primary source of contamination was the SRTC complex. A secondary source of contamination is the Met Lab Basin that received waste effluent from the Metallurgical Laboratory manufacturing facilities.

Waste entered the Met Lab Basin via an underground process sewer line. During periods of heavy rainfall, wastewater and surface runoff overtopped a drainage outfall at the Met Lab and were discharged to an adjacent Carolina bay. This entire area is referred to as the Met Lab HWMF.

The effluent discharged to the unlined Met Lab Basin consisted primarily of noncontact cooling water and small quantities of laboratory rinse water from metallographic sample preparation (degreasing, etching, and cleaning) and corrosion testing of stainless steels and nickel-based alloys. Most of the metals were effectively captured in the basin's sediments. Approximately 700 liters of 1,1,1- trichloroethane, trichloroethylene and tetrachlormethane (chlorinated degreasing solvents) were released to the basin. Some of the solvents seeped into the subsurface, contaminating the soil and groundwater, the remainder evaporated.

Subsequent to the termination of hazardous waste release to the Met Lab Basin in 1983, SRS established a corrective action program that includes extensive groundwater monitoring and groundwater recovery for treatment. The Met Lab Basin was certified closed in 1992 per Resource Conservation and Recovery Act (RCRA) requirements.

The closure and the groundwater remediation activities have been conducted in compliance with the South Carolina Department of Health and Environmental Control (SCDHEC) requirements. As part of SCDHEC requirements, periodic reports on the remediation program's effectiveness are required.

Hydrogeological characterization represents one of the methods utilized in the continued assessment of the remediation program's effectiveness. The work presented herein represents the first phase of characterization efforts conducted in the Met Lab HWMF. The Met Lab HWMF contaminant plume is just outside the influence of the M-Area groundwater recovery 
system. SRS intends to further investigate the Met Lab HWMF to determine the magnitude and extent of solvent contamination so that informed decisions can be made regarding remediation measures.

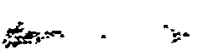




\subsection{Phase I Characterization: Monitor Well Installation, Soil Coring and Cone Penetrometer Testing}

As part of the ongoing corrective action program in the A/M Area, SRS is performing characterization studies to obtain additional hydrogeologic and soil/groundwater quality information necessary to define the vertical and lateral extent of solvent contamination in the M-Area and Lost Lake aquifer zones of the Steed Pond Aquifer.

This assessment included the drilling of soil corings for geotechnical and soil headspace analysis.

\subsection{Monitor Well Installation}

A total of seven additional monitor wells were installed in the vicinity of the Met Lab HWMF. Two wells (AMB-17A and 18A) were screened in the middle sand aquifer zone of the Crouch Branch confining unit; two wells (AMB-18C and 19C) were screened in the upper part of the Lost Lake aquifer zone; and three wells (AMB-14D, 15D, and 16D) were screened across the M-Area aquifer zone (water table). Mud rotary drilling methods were deployed to install the monitor wells. A summary of the monitor well construction details is presented in Table 1; complete well installation details are presented in Appendix A.

\subsection{Soil Coring}

During 1994, a Phase I Characterization was initiated in the Met Lab HWMF which included drilling (mud rotary method) one corehole (AMB-SB1), geophysical logging and sampling of the core for VÓC analysis. Figure 1 and Table 1 depict the corehole location and details. AMB-SB 1 was drilled at the southeast corner of Building 723-A. This location was selected based on its proximity to the former process sewer line which ran from Building 723-A to the Met Lab Basin.

Data collected included lithologic descriptions, geophysical logs (Appendix A) and VOC analytical results (Table 2).

Discrete sediment samples for analysis of VOCs were collected during the drilling activities. Sediment samples for headspace analysis of VOCs were collected in 10-foot intervals from the surface to a depth of 290 feet from one corehole by SRTC Environmental Sciences Section 
Table 1. Well Construction and Soil Boring Details

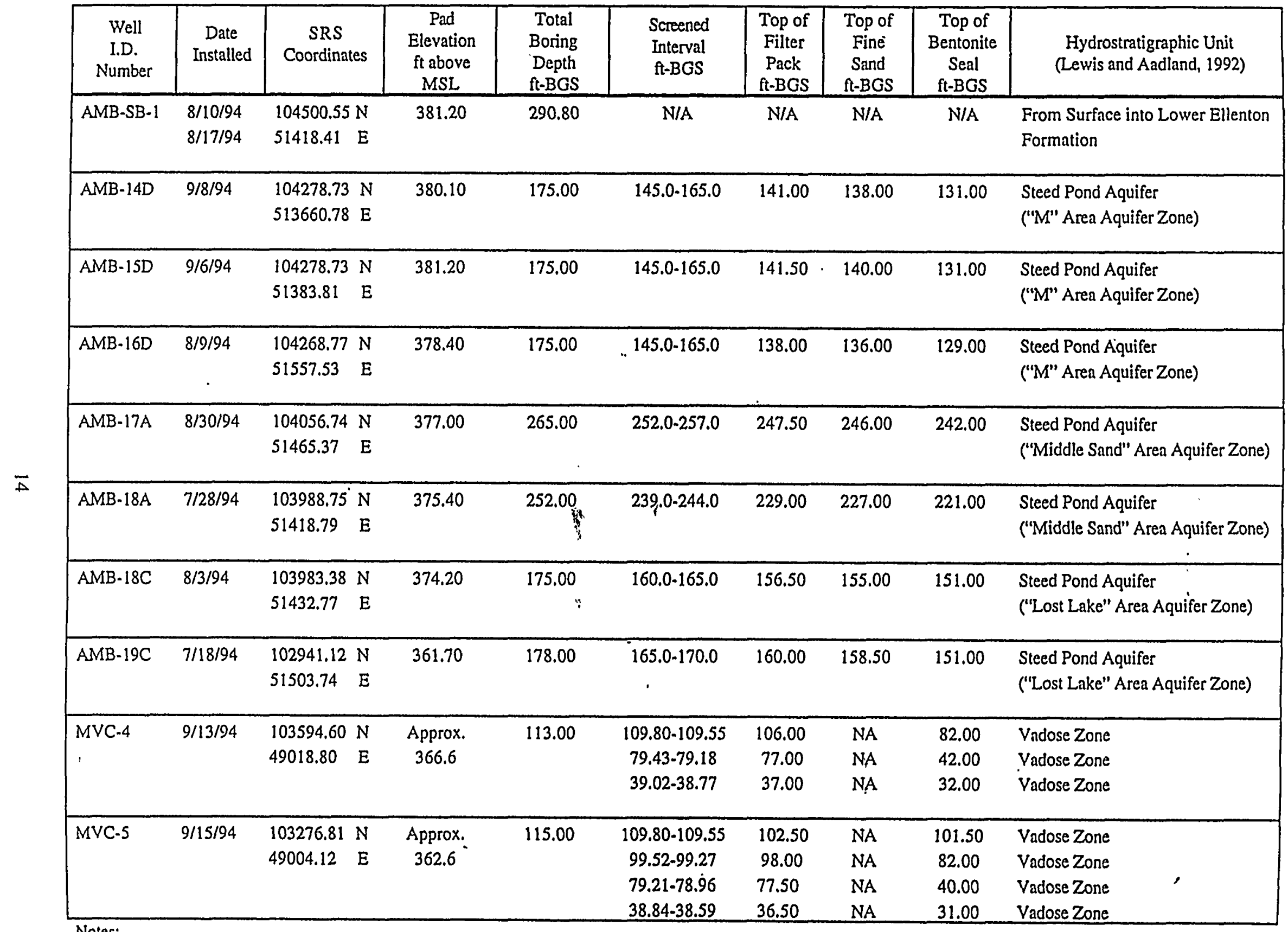


Table 2. Bulk Sediment Headspace Results and Estimated Groundwater Concentrations

\begin{tabular}{|c|c|c|c|c|c|c|c|c|c|}
\hline \multirow{2}{*}{$\begin{array}{l}\text { Well I.D. } \\
\text { AMB-SB1 }\end{array}$} & \multirow{2}{*}{$\begin{array}{c}\begin{array}{c}\text { Depth } \\
\text { feet }\end{array} \\
12\end{array}$} & \multirow{2}{*}{$\begin{array}{c}\text { TCE } \\
\text { sediment conc. } \\
\mu \mathrm{g} / \mathrm{g}\end{array}$} & \multirow{2}{*}{$\begin{array}{c}\text { PCE } \\
\text { sediment conc. } \\
\mu \mathrm{g} / \mathrm{g} \\
<0.001\end{array}$} & \multicolumn{3}{|c|}{$\begin{array}{c}\text { TCE } \\
\text { Estimated Groundwater } \\
\text { Concentration Range } \mu g / L \\
\end{array}$} & \multicolumn{3}{|c|}{$\begin{array}{c}\text { TCE } \\
\text { Estimated Groundwater } \\
\text { Concentration Range } \mu \mathrm{g} / \mathrm{L}\end{array}$} \\
\hline & & & & & N/A & & & N/A & \\
\hline AMB-SB1 & 22 & $<0.001$ & $<0.001$ & & N/A & & & N/A & \\
\hline AMB-SB 1 & 32 & 0.002 & 0.002 & & N/A & & & N/A & \\
\hline AMB-SB 1 & 42 & 0.001 & 0.001 & & N/A & & & N/A & \\
\hline AMB-SB1 & 52 & 0.006 & 0.006 & & N/A & & & N/A & \\
\hline AMB-SB I & 62 & 0.005 & 0.005 & & N/A & & & N/A & \\
\hline AMB-SB1 & 67 & 0.002 & 0.001 & & N/A & & & N/A & \\
\hline AMB-SB 1 & 72 & 0.011 & 0.010 & & N/A & & & N/A & \\
\hline AMB-SB 1 & 77 & 0.011 & 0.009 & & N/A & & & $\vec{N} / A$ & \\
\hline AMB-SB1 & 82 & 0.017 & 0.015 & & N/A & & & N/A & \\
\hline AMB-SB1 & 87 & 0.032 & 0.025 & & N/A & & & N/A & \\
\hline AMB-SBI & 92 & $<0.001$ & $<0.001$ & & N/A & & & N/A & \\
\hline AMB-SB1 & 97 & 0.017 & 0.011 & & N/A & & & N/A & \\
\hline AMB-SB1 & 102 & $<0.001$ & $<0.001$ & & N/A & & & N/A & \\
\hline AMB-SB 1 & 107 & 0.035 & 0.023 & & N/A & & & N/A & \\
\hline AMB-SB 1 & 112 & 0.068 & 0.030 & & N/A & & & N/A & \\
\hline AMB-SB 1 & 117 & 0.013 & 0.005 & & N/A & & & N/A & \\
\hline AMB-SB1 & 122 & 0.021 & 0.007 & - & N/A & & & N/A & \\
\hline AMB-SB1 & 127 & 0.035 & 0.011 & & N/A & & & N/A & \\
\hline AMB-SB1 & 132 & 0.003 & $<0.001$ & & N/A & & & N/A & \\
\hline AMB-SB1 & 137 & 0.040 & 0.007 & 80 & to & 200 & 14 & to & 35 \\
\hline AMB-SB 1 & 142 & 0.012 & 0.002 & 23 & to & 59 & 4 & to & 10 \\
\hline AMB-SB 1 & 147 & 0.009 & 0.002 & 18 & to & 46 & 3 & to & 8 \\
\hline AMB-SB1 & 152 & 0.012 & 0.002 & 23 & to & 58 & 4 & to & 10 \\
\hline AMB-SB1 & 162 & $<0.001$ & $<0.001$ & $<2$ & to & $<5$ & $<2$ & to & $<5$ \\
\hline AMB-SB 1 & 172 & $<0.001$ & $<0.001$ & $<2$ & to & $<5$ & $<2$ & to & $<5$ \\
\hline AMB-SB 1 & 182 & $<0.001$ & $<0.001$ & $<2$ & to & $<5$ & $<2$ & to & $<5$ \\
\hline AMB-SB 1 & 192 & 0.002 & $<0.001$ & 5 & to & 12 & $<2$ & to & $<5$ \\
\hline AMB-SB 1 & 202 & $<0.001$ & $<0.001$ & $<2$ & to & $<5$ & $<2$ & to & $<5$ \\
\hline AMB-SB 1 & 212 & 0.032 & 0.002 & 64 & to & 160 & 5 & to & 12 \\
\hline AMB-SB1 & 222 & 0.005 & $<0.001$ & 10 & to & 26 & $<2$ & to & $<5$ \\
\hline AMB-SB 1 & 232 & 0.002 & $<0.001$ & 3 & to & 8 & $<2$ & to & $<5$ \\
\hline AMB-SB 1 & 240 & 0.010 & 0.001 & 19 & to & 48. & 2 & to & 6 \\
\hline AMB-SB 1 & 252 & $<0.001$ & $<0.001$ & $<2$ & to & $<5$ & $<2$ & to & $<5$ \\
\hline AMB-SB 1 & 262 & 0.543 & 0.074 & 1087 & to & 2717 & 148 & to & 371 \\
\hline AMB-SB 1 & 272 & 0.337 & 0.026 & 675 & to & 1687 & 52 & to & 131 \\
\hline AMB-SB 1 & 282 & $<0.001$ & $<0.001$ & $<2$ & to & $<5$ & $<2$ & to & $<5$ \\
\hline
\end{tabular}

N/A - not applicable, above water table 
(ESS) field technicians. A complete description of the sample methodology is presented in Looney et al, 1993.

The sediment samples were collected by inserting a 12-millimeter diameter open-ended plastic disposable syringe into several discrete locations over the basal half-foot interval of the core until approximately three to five cubic centimeters of sediment were collected. Immediately following, the sample was extruded into a 25-millimeter borosilicate beaker. Approximately five millimeters of suspending solution (deionized water) was added to the sample. The beakers were sealed with Parafilm and refrigerated to approximately $4^{\circ} \mathrm{C}$ for VOC analysis at an onsite laboratory.

Results from the headspace analysis are presented in Section 4.2.1.

\subsubsection{Soil Core Laboratory Analysis for Volatile Organic Compounds (VOCs)}

Bulk samples $\left(3-5 \mathrm{~cm}^{3}\right)$ were collected and analyzed for chlorinated VOCs by SRTC-ESS. The samples were analyzed using a static headspace method originally developed to support SRS groundwater VOC remediation activities. A detailed description of the SRTC-ESS method is provided in Looney et al., 1993.

\section{Laboratory Results}

The data for each sample location are summarized in Table 2. A total of 37 sample points were selected for analysis.

The primary analyses were for TCE (trichloroethylene) and PCE (tetrachloroethylene). The VOC concentrations range from below detection $(<0.00 \mu \mathrm{g} / \mathrm{g})$ to $0.588 \mu \mathrm{g} / \mathrm{g}$. Approximately 27 $\%$ (10 samples) of the samples were below detection for both compounds. Maximum TCE and PCE concentrations $(0.588$ and $0.078 \mu \mathrm{g} / \mathrm{g}$, respectively) were detected at a depth of 262 feet. Elevated concentrations of TCE and PCE occur at depths from 32 to 97 feet; 107 to 152 feet; 192 to 240 feet; and 262 to 272 feet. 
Based on examination of the field geologic descriptions, these sample depths containing VOCs represent unsaturated and water bearing zones between or just above/below fine grain sediments. All of the above findings and observations are discussed below in more detail.

Estimated groundwater TCE and PCE concentrations are also obtained from the soil headspace data. An apparent relationship exists between depth discrete bulk sediment and groundwater concentrations at the sample depth, as indicated by previous studies in the A/M Area (Looney et al., 1993). Essentially, the groundwater concentration $(\mu \mathrm{g} / \mathrm{L})$ is 2000 to 5000 times the bulk sediment concentration $(\mu \mathrm{g} / \mathrm{g}$ ) (Looney et al., 1993). For the purposes of this report, the higher value was utilized. That is, the bulk sediment concentrations $(\mu \mathrm{g} / \mathrm{g})$ were multiplied by 5000 to obtain the most conservative estimated groundwater values (reported in $\mu \mathrm{g} / \mathrm{L}$ ).

Soil headspace results (in the form of estimated groundwater concentrations) were also compared to the corresponding lithology. Twenty-seven (27) samples representing core AMB-SB1 exhibit TCE and/or PCE concentrations above detection levels. Results from these samples are compared to the corresponding lithology and discussed below. A review of the data suggests a general correlation between fluctuations in VOC concentrations and lithology.

This is most evident at the depth interval of 260 to 270 feet, where intervals with a dominant sandy lithology having a much higher VOC concentration, are interbedded with intervals of finer-grained clayey material having a much lower $\mathrm{OC}$ concentration. It appears that the underlying finer-grained material is retarding the downward movement of the VOCs, allowing for an increase in concentration in the coarser-grained sandy material.

\section{AMB-SB1}

This boring was sampled at ten-foot intervals from the depths of 12 to 282 feet below the surface. TCE and PCE concentration levels are elevated (up to $0.588 \mu \mathrm{g} / \mathrm{g}$; equivalent to parts per million in groundwater phase) within the sampled intervals at 32 to 97 feet; 107 to 152 feet; 192 to 240 feet ; and 262 to 272 feet below surface. These sampled intervals correspond to both the vadose (unsaturated) and saturated zones. The top of the saturated zone occurs at a depth of approximately 137 feet below surface. 
Vadose Zone:

TCE and PCE concentrations, ranging up to 0.077 and $0.035 \mu \mathrm{g} / \mathrm{g}$ respectively, occur within the vadose zone. An increasing trend in both TCE and PCE concentrations occurs from a depth of 32 to 112 feet below surface. At the depth of 112 feet, both TCE and PCE attain maximum concentrations. Lithologically, this 80 foot interval is represented by fine to medium grain sands with 10 to $30 \%$ clay. At a depth of 111-112 feet, an increase in clay (in the form of clay lenses) is observed. Correspondingly, a decrease in TCE and PCE concentrations (0.017 and 0.006 $\mu \mathrm{g} / \mathrm{g}$, respectively) occurs immediately below this lithological change. Both TCE and PCE levels ( 0.035 and $0.012 \mu \mathrm{g} / \mathrm{g}$, respectively) increase again from a depth of 117 to 127 feet. This is associated with a lithological change towards fine to medium sands with 10 to $15 \%$ clay content. Contaminant levels (0.004 and $0.001 \mu \mathrm{g} / \mathrm{g}$, respectively) decrease again at the 132 foot interval; however, this trend does not appear'associated with a change in lithology.

Saturated Zone:

As stated earlier, estimated groundwater TCE and PCE concentrations have also been obtained from the soil headspace data and are used herein. The upper part of the saturated zone is interpreted at approximately 137 feet below surface. At this interval, TCE and PCE concentrations are reported as 225 and $40 \mu \mathrm{g} / \mathrm{L}$ (equivalent to 0.045 and $0.008 \mu \mathrm{g} / \mathrm{g}$ ), respectively. A decreasing trend is observed from this interval to a depth of approximately 162 feet. This is associated with a change towards an increase in clay content at a depth of 150 to 155 feet. Within this interval, clays comprise up to $35 \%$ of the sediments. A decrease in clay content $(\sim 10-15 \%)$ is observed from a depth of 155 to 230 feet below surface. Associated with this lithological change is a decrease (with the exception of the 212 foot interval) in contaminant levels.

TCE occurs at concentrations of approximately $30 \mu \mathrm{g} / \mathrm{L}$ or less, whereas PCE is present at levels of $5 \mu \mathrm{g} / \mathrm{L}$. The exception is at the 212 foot interval where TCE and PCE occur at concentrations of 225 and $20 \mu \mathrm{g} / \mathrm{L}$, respectively.

Lithologically, the sediments comprising this interval include fine grain sands with a minor $(<10 \%)$ amount of clay, which are similar to the over- and underlying intervals. 
TCE and PCE exhibit concentrations equivalent to, or less than 50 and $5 \mu \mathrm{g} / \mathrm{L}$, respectively within the 222 to 240 foot interval. Lithologically, this interval is represented by medium to coarse sands with minor amounts of clay. However, a two-foot thick indurated clay occurs at a depth of approximately 230 feet below surface. TCE levels immediately above and below the clay occur as 30 and $50 \mu \mathrm{g} / \mathrm{L}$, respectively; PCE concentrations are recorded as $5 \mu \mathrm{g} / \mathrm{L}$.

At a depth of approximately 252 feet, a sudden increase in PCE concentrations ( $390 \mu \mathrm{g} / \mathrm{L})$ is observed. At this interval, TCE is not detected above concentrations of $5 \mu \mathrm{g} / \mathrm{L}$. However, at a depth of 262 feet, TCE concentrations suddenly increase to $2940 \mu \mathrm{g} / \mathrm{L}$; PCE occurs as $390 \mu \mathrm{g} / \mathrm{L}$. Both TCE and PCE concentrations (2335 and $175 \mu \mathrm{g} / \mathrm{L}$, respectively) remain relatively high to a depth of approximately 272 feet. Lithologically, the interval from 252 to 275 is comprised predominantly of medium to coarse sands with minor clay content. However, an increase in clay is observed at the 266-267 and 270 to 275 foot intervals. These depth ranges are approximate as the intervals exhibit less than $50 \%$ core recovery.

A reduction in both TCE and PCE concentrations $(5 \mu \mathrm{g} / \mathrm{L})$ occurs in the underlying 282 foot interval. Lithologically, this interval is represented by an indurated clay which is at least six feet in thickness. The corehole was terminated at a depth of approximately 291 feet below surface.

\subsection{Cone Penetrometer Testing}

Six cone penetrometer testings (CPT) were initiated within the vicinity of the Met Lab HWMF. The purpose of the testings was to provide a screening tool for optimal placement of the three water table plume definition wells. Information collected during the testings included geotechnical (tip resistance, sleeve friction, pore pressure, and electrical resistivity) and sampling for soil vapor and groundwater.

Data obtained from this study was used to generate the cross-sectional hydrostratigraphic and isoconcentration plume maps. Below is a brief discussion of the field methods, including the geotechnical testing and sampling.

Field Methods:

A 24-ton truck hydraulic mounted cone penetrometer system was used to conduct the CPT testings. Tip resistance, sleeve friction, pore pressure, and electrical resistivity are independently 
measured through sensors built into a probe which is attached to a series of hollow carbon steel rods ( 3 foot lengths; 1.7 inch diameter) that are hydraulically pushed into the subsurface against the weight of the truck. Data is collected every inch and transmitted via an electric cable strung through the rods to a data acquisition system (computer) located inside the truck. As a result, real-time is generated and displayed as it is being collected. This allows for rapid interpretation of the data and timely field adjustments, if required.

In addition to the geotechnical measurements, soil vapor and groundwater samples were collected at selected locations. A teflon bellows vacuum pump was used in combination with the Bruel and Kjaer unit and SRS-SRTC patented Cone Sipper sampling tool for soil vapor readings. Sampling was conducted at one location (MLCP4) suspected of vadose contamination based on facility history.

Groundwater samples were obtained at discrete depths using an SRS developed Cone-Sipper continuous sampler and a Fugro, Inc. hydrocone sampler/bailer system. The Cone-Sipper is a gas-lift pump incorporating a miniature electronic solenoid valve that is installed in a cone penetrometer tip. The pump allows sampling of gas and liquid at multiple depths without exiting and re-entering the hole. The sample instrument is attached to the cone rods and advanced to a desired depth. Upon reaching the target depth, the solenoid valve is opened and a vacuum is applied to the system to collect a sample in the tubing. After allowing sufficient time for sample collection, the solenoid valve is closed and the vacuurfis disengaged. Nitrogen gas pressure is applied to the vacuum tubing in order to force the sample through the system and out the sample tubing. Once the sample has been purged and collected into a sample container, the solenoid valve can be reclosed and additional samples can be collected at that depth or the sampler can be advanced to a different depth for sample collection.

The Fugro, Inc. groundwater sampler/bailer system is comprised of a stainless-steel sampler body with a sacrificial conical tip. The sampler body and sacrificial tip are assembled, attached to the cone rods, and advanced to the target sampling depth. Upon reaching the sampling depth, the cone rods and attached sampler are retracted approximately 18 inches, leaving the sacrificial tip in place, and the sampler is allowed to fill by inflow from the aquifer. After sufficient volume has collected in the sample chamber, the sample is collected using a stainless-steel sampling bailer. 
Following completion of geotechnical and vapor/groundwater sampling, each CPT location was grouted from target depth to surface using the grout-through-rod method. This method involves advancing grouting rods to the target depth, and releasing grout as rods are withdrawn from the testing location. All grouting activities were performed in accordance with WSRC-3Q5 procedures.

Soil Vapor Sampling Results:

Soil vapor samples were obtained at cone penetrometer location MLCP4 (Figure 1 - southeast corner of building 730-A) from depths of approximately 65 and 120 feet below surface. Results indicate concentrations of TCE and PCE at approximately 34 ppmv at a depth of 65 feet; TCE and PCE concentrations of 8.5 and 5.4 ppmv, respectively were detected at a depth of 120 feet. These results indicate the presence of TCE and PCE within the vadose zone at levels significantly higher than recorded from the saturated zone within the vicinity of the Met Lab HWMF.

Groundwater Sampling Results:

Groundwater sampling was attempted at six cone penetrometer locations. However, sampling was successful at only two locations, MLCP2 and MLCP4; the remaining four locations (MLCP $1,3,5$, and 6) were unsuccessful due to refusal of the cone rods prior to reaching the saturated zone.

Initially, the SRTC Cone Sipper was deployed to collect groundwater samples. However, technical problems with the sampler necessitated the use of the Fugro sampler/bailer system for all groundwater sampling associated with this project.

All groundwater samples were transported to an on-site laboratory for analysis. Two analytical methods were used to quantify VOC concentrations in aqueous-phase samples (gas chromatography and direct sampling ion trap mass spectrometry).

In addition to the subsurface samples, quality control samples were also taken; field and trip blanks were taken at each location. Results indicate an absence of VOCs in all field and trip blanks. 
Table 3 presents the depth and analysis for each sample taken (excluding field and trip blanks). Each groundwater sample was analyzed for Volatile Organic Compounds (VOCs).

\section{Discussion}

Information collected from the cone penetrometer testings and soil boring, in combination with existing monitor well data (2nd quarter 1994) was utilized to construct isoconcentration contaminant plume maps (cross-sectional view) to depict TCE and PCE concentration in the Metallurgical Laboratory HWMF.

The water quality data obtained from the soil boring is by nature not the same as that produced from monitor wells. Monitor wells will, by virtue of the way the sample is collected, exhibit an average of the water quality data over the interval where the upper and lower sand pack and screen zone are located in the well bore. This results in a water sample that is representative of 5 to 20 feet of vertical extent. In contrast, the headspace data acquired from soil boring sampling is derived from depth-discrete intervals within the subsurface and are contoured as such. In addition, the soil boring water quality data represents an estimate of the contaminants derived from physical core samples. The comparison is made that estimates from the soil borings would represent an average over a specific interval in the well boring.

As shown in Figures 4 through 7, the higher concentrafron plumes are located in the middle sand aquifer zone within the vicinity of boring AMB-1SB (located northwest of the Met Lab Basin) and wells AMB-4A (located immediately adjacent to the Met Lab Basin) and AMB-7A (located immediately southeast of the Met Lab Basin).

The highest concentrations of TCE (up to $2940 \mathrm{ppb}$ in AMB-SB1) occur within the middle sand aquifer zone as well as in the uppermost part of the lower clay confining zone of the Crouch Branch confining unit.

PCE concentrations follow a similar pattern in distribution. However, they are much lower than the TCE concentrations.

Groundwater plume data (in form of cross-sectional and planar plume maps) presented in the 1995 report "Hydrogeologic Framework for the Metallurgical Laboratory Basin Area" (WSRC-RP-95-54) support the findings presented herein. 
Table 3. Groundwater Sample Location, Depth, and Analysis

\begin{tabular}{|l|c|c|c|}
\hline \multicolumn{1}{|c|}{ Sample Location } & Sample Depth (ft) & TCE $(\mu \mathrm{g} / \mathrm{L})$ & $\underline{\text { PCE }(\mu \mathrm{g} / \mathrm{L})}$ \\
\hline MLCP2-1 & 155.0 & 12 & 4 \\
MLCP2-1D & 155.0 & 12 & 4 \\
MLCP4-2 & 153.9 & 118 & 46 \\
MLCP4-2D & 153.9 & 114 & 45 \\
MLCP4-3 & 155.0 & 108 & 41 \\
MLCP4-3D & 155.0 & 110 & 43 \\
\hline
\end{tabular}

$\mathrm{D}=$ duplicate sample;

MLCP4 was sampled using the Cone Sipper;

MLCP2 was sampled using the Fugro Hydrocone. 
Both the planar and cross-sectional plume maps indicate that the highest concentration of TCE and PCE contamination is concentrated within the vicinity of soil boring AMB-SB1 and wells $\mathrm{AMB}-4 \mathrm{~A}$ and $7 \mathrm{~A}$.

With respect to the Crouch Branch aquifer, none of the wells or intervals sampled in the soil boring penetrated the aquifer. The intent of this project was to characterize the middle sand and overlying aquifer zones. Information on the extent of contamination within the Crouch Branch aquifer is presented in separate documents.

Overall, the isoconcentration maps depict a fairly predictable pattern in that the highest concentrations (middle sand aquifer zone) are centered upgradient of the Met Lab Basin and probably represent a migration of a plume originating within known source areas upgradient of the Met Lab HWMF, i.e., Savannah River Technology Center. However, the soil vapor data from cone penetrometer investigations in the vadose zone also suggest the presence of TCE and PCE (34 ppmv) at depths of 65 feet below surface at the southeast corner of Building 730-A. TCE and PCE were also recorded at concentrations of up to 8 ppmv at depths of 120 feet in the same vicinity. As a result, a second phase of characterization will be conducted to determine the extent of vadose zone contamination in the vicinity of Building 723-A.

The data presented herein is in agreement with previous interpretations as presented in the 1994 M-Area RCRA Part B Permit Application Revision ăfid 1994M-Area Groundwater Quarterly Report. However, this report represents the integration of newly acquired data along with existing data utilized in the aforementioned documents. Hence, this report represents the most comprehensive interpretation of the hydrogeology and TCE and PCE contaminant distribution within the Met Lab HWMF.

\subsection{Future Studies}

As part of the on-going corrective action program in the A/M-Area, SRS has obtained (through Phase I efforts) additional hydrogeologic and groundwater quality information necessary for definition of the vertical and lateral extent of solvent contamination in the vicinity of the Metallurgical Laboratory. This work also satisfies a regulatory commitment to SCDHEC to install monitor wells downgradient of the M Area, Lost Lake, and middle sand aquifer zones. To date, plans have been formulated for a second phase of characterization which will focus on the vadose zone within the vicinity of Building 723-A. This study will utilize proven investigative 
methods such as soil coring for soil headspace analyses and cone penetrometer testing for geotechnical, soil vapor and groundwater sampling. A detailed scope was submitted to SCDHEC for review on 11/7/94 (Cook to Ede letter); SCDHEC approval for this work was granted on 11/21/94 (Ede to Cook letter). The work is planned for the fall/winter of 1995 . 


\subsection{CONCLUSIONS}

A summary of the findings associated with the Metallurgical Laboratory Phase I Characterization of chlorinated solvent (TCE, PCE) contamination in the Tertiary aquifers underlying the $\mathrm{A} / \mathrm{M}$ Area of the SRS has been provided.

In the vicinity of the Metallurgical Laboratory HWMF, the contaminant plume in the uppermost aquifer is the result of past disposal practices of waste solvents (primarily, TCE and PCE) associated with activities in the A/M Area facilities, probably upgradient of the Met Lab HWMF.

Laboratory results from the soil headspace analysis of 37 samples from one soil boring location, and groundwater and soil gas sampling from two cone penetrometer locations indicate the presence of TCE or PCE concentrations above detection in coreholes AMB-SB1. The VOC concentration ranged from less than detection to $2940 \mu \mathrm{g} / \mathrm{L}$. Maximum TCE and PCE concentrations $(2940 \mu \mathrm{g} / \mathrm{L}$ and $390 \mu \mathrm{g} / \mathrm{L}$, respectively) were observed in samples from AMB-SB1.

Two cone penetrometer locations, MLCP2 and MLCP4, indicated the presence of TCE (up to $118 \mathrm{ppb}$ ) and PCE (up to $46 \mathrm{ppb}$ ) in groundwater samples from depths of 153 to 155 feet. These depths correspond hydrostratigraphically to the M-Area aquifer zone.

Information collected from the soil borings, in combination with existing monitor well data (2nd quarter 1994), was utilized to construct isoconcentration contaminant plume maps (planar and cross-sectional view) to depict TCE and PCE concentration in the Met Lab HWMF.

Estimated TCE and PCE groundwater concentrations from monitor wells AMB-4A and 7A and soil boring AMB-SB1 indicate that the solvent contamination is concentrated within the M-Area aquifer zone, throughout both the upper and lower portions of the Lost Lake aquifer zone, and into the middle sand aquifer zone. The highest concentrations of TCE and PCE generally occur within the middle sand aquifer zone.

The results of this investigation corroborate previous interpretations (as presented in the 1994 Metallurgical Laboratory Part B Permit Application Revision and 1994 Metallurgical Laboratory Groundwater Quarterly Report) which suggest that the primary source of TCE and PCE contamination in the Metallurgical Laboratory HWMF is from upgradient sources, i.e. building 
321-M and storage solvent areas, and SRTC laboratories. Distribution of the VOC concentrations suggest that the contaminants are primarily moving above the surface of lower permeability zones within the $M$ Area (water table) and Lost Lake aquifer zones. However, VOC contamination is also present within the middle sand aquifer zone. This suggests that contamination is either moving vertically within the source area and/or is moving laterally in each of these aquifer zones from sources upgradient of the Metallurgical Laboratory HWMF. Based on historical use of chlorinated waste products in the A/M Area, contamination in the middle sand aquifer zone underneath the Met lab HWMF is due to lateral migration from an upgradient source (most likely the SRTC laboratories). 


\subsection{REFERENCES}

Aadland, R.K., Lewis, S.E., and McAdams, T.D., 1995. Hydrogeologic Framework for the A/M Area $(U)$, WSRC-RP-95-52, Westinghouse Savannah River Company.

Aadland, R.K., Lewis, S.E., and McAdams, T.D., 1995. Hydrogeologic Framework for the Metallurgical Laboratory Basin Area (U), WSRC-RP-95-54, Westinghouse Savannah River Company.

Aadland, R.K. and H.W. Bledsoe, 1990. Classification of Hydrostratigraphic Units at the Savannah River Site, South Carolina, WSRC-RP-90-987, Westinghouse Savannah River Company.

Aadland, R.K., A.D. Smits, and P.A. Thayer, 1992. Geology and Hydrostratigraphy of the A/M Area, Savannah River Site (SRS), South Carolina (U), WSRC-RP-92-440, Westinghouse Savannah River Company, Savannah River Site, Aiken, SC 29808.

Fallaw, W.C., 1991, Subsurface Stratigraphy and Structure of the A/M Area at the Savannah River Site. USDOE Report WSRC-RP-91-830, Westinghouse Savannah River Co., Westinghouse Savannah River Laboratory, Aiken, SC 29808, 96 p.

Klitgord, K.D. and Behrendt, J.C., 1979, "Basin Structure of the U.S. Atlantic Margin". Geological and Geophysical Investigations of Continental Margins. American Association of Petroleum Geologists Memoir 29, eds. J.S. Watkins, L. Montadert, and P.W. Dickerson, pp. 85-112.

Lewis, S.E. and Aadland, R.K., 1994, Hydrogeologic Setting of the A/M Area: Framework for Groundwater Transport (U). USDOE Report WSRC-TR-92-355, Westinghouse Savannah River Co., Westinghouse Savannah River Laboratory, Aiken, SC 29808.

Looney, B.B., C.A. Eddy, and W.R. Sims, 1993. Evaluation of Headspace Method for Volatile Constituents in Soils and Sediments. In: Measuring and Interpreting VOCs in Soils: State of the Art and Research Needs, U.S. Environmental Protection Agency, Environmental Monitoring Systems Laboratory, Las Vegas NV 89193.

Siple, G.E., 1967, Geology and Groundwater of the Savannah River Plant and Vicinity, South Carolina, U.S. Geological Survey, Water Supply Paper 1841.

WSRC, Rev. 11992 RCRA Part B Permit Renewal Application, M-Area HWMF (U), WSRC-IM-91-53-Vol-3-Boot-1, Feb. 1993, Aiken, SC (WSRC, 1993).

WSRC, 1993. Hydrogeologic Data Collection Methods, Procedures and Specifications, WSRC 3 Q5 (formerly DPSOP 254), adapted by WSRC from E.I. du Pont de Nemours and Company, Savannah River Site, Aiken, SC 29808. 
NOTICE

Page(s) size did not permit electronic reproduction. Information may be purchased by the general public from the National Technical Information Service, U.S. Department of Commerce, Springfield, VA 22161 (Area Code 703-487-4650). DOE and DOE contractors may purchase information by contacting DOE's Office of Scientific and Technical Information, P.O. Box 62, Oak Ridge, TN 37831, Attn: Information Services (Area Code 423-576-8401). 